\title{
Composition, content of bioactive compounds, and antioxidant activity of fruit pulps from the Brazilian Amazon biome
}

\author{
Lara Borghi Virgolin(1), Fernanda Rosan Fortunato Seixas ${ }^{(1)}$ and Natália Soares Janzantti ${ }^{(1)}$
}

(1)Universidade Estadual Paulista, Departamento de Engenharia e Tecnologia de Alimentos, Rua Cristóvão Colombo, ํo2.265, CEP 15054-000 São José do Rio Preto, SP, Brazil. E-mail: lara_borghi@hotmail.com, ferseixas@hotmail.com, natalia@ibilce.unesp.br

\begin{abstract}
The objective of this work was to evaluate the physicochemical composition, the bioactive compounds, and the total antioxidant activity of the fruit pulps of abiu (Pouteria caimito), achachairu (Garcinia humilis), araza (Eugenia stipitata), bilimbi (Averrhoa bilimbi), and yellow mangosteen (Garcinia xanthochymus) from the Brazilian Amazon biome. Total soluble solid content, total and reducing sugar contents, titratable acidity contents, $\mathrm{pH}$, ascorbic acid content, moisture, protein, lipid, ash, and caloric value were determined. The contents of total anthocyanins, yellow flavonoids, and total carotenoids, besides total phenolic compounds and antioxidant activity, were also evaluated. The abiu pulp showed the highest contents of ash, total sugars, reducing sugars, total soluble solids, calorie value, and $\mathrm{pH}$, among the analyzed fruits. The achachairu pulp showed the highest content of total phenolic compounds, with significant antioxidant activity, while the araza pulp had the highest total carotenoid content, and the yellow mangosteen, the highest yellow flavonoid content. The positive correlation between antioxidant activity and total phenolic compounds suggests that these compounds are the most important for determining antioxidant activity in the evaluated fruit pulps.
\end{abstract}

Index terms: Amazon biome, exotic fruit, fruit physicochemical composition, macronutrients, micronutrients.

\section{Composição, teor de compostos bioativos e atividade antioxidante de polpas de frutas do bioma Amazônia}

\begin{abstract}
Resumo - O objetivo deste trabalho foi avaliar a composição físico-química, os compostos bioativos e a atividade antioxidante total das polpas das frutas de abiu (Pouteria caimito), achachairu (Garcinia humilis), araçá-boi (Eugenia stipitata), biri-biri (Averrhoa bilimbi) e mangostão-amarelo (Garcinia xanthochymus), procedentes do bioma Amazônia no Brasil. Foram determinados os teores de sólidos solúveis totais, açúcares redutores e totais, acidez total titulável, $\mathrm{pH}$, ácido ascórbico, umidade, proteínas, lipídeos, cinzas e valor energético total. Os teores de antocianinas totais, flavonoides amarelos e carotenoides totais, além dos compostos fenólicos totais e atividade antioxidante, também foram avaliados. A polpa de abiu apresentou os maiores teores de cinzas, açúcares totais, açúcares redutores, sólidos solúveis totais, valor energético total e $\mathrm{pH}$, entre as frutas avaliadas. A polpa de achachairu apresentou o maior teor de compostos fenólicos totais com significativa atividade antioxidante, enquanto a polpa de araçá-boi apresentou o maior teor de carotenoides totais, e a polpa de mangostão-amarelo apresentou o maior teor de flavonoides amarelos. A correlação positiva entre a atividade antioxidante total e o teor de compostos fenólicos totais mostra que estes são os compostos mais importantes para a determinação da atividade antioxidante das polpas das frutas analisadas.
\end{abstract}

Termos para indexação: bioma Amazônia, frutas exóticas, parâmetros físico-químicos das frutas, macronutrientes, micronutrientes.

\section{Introduction}

Fruit consumption has increased in both Brazilian and international markets as a result of the increased awareness of the nutritional value and health benefits of fruit, and also as a result of new consumer habits generated by increased concerns over the relationship between diet and health (Liu, 2013). Some bioactive constituents present in fruit, such as vitamins, carotenoids, and phenolic compounds, are associated with the prevention of a series of chronic pathologies including cancer, cardiovascular disease, type-2 diabetes, and Alzheimer's disease (Carter et al., 2010; Wang et al., 2011).

Brazil's territory extends over 8.5 million $\mathrm{km}^{2}$. Its temperate and tropical climates, and soil conditions make fruit production one of the country's main 
agribusiness activities. The country is the world's third largest fruit producer, and is also one of the most biologically diverse regions in the world. Brazil's large quantities of native fruit species, which are considered exotic in flavor, attract consumers from around the globe (FAO, 2013; Anuário..., 2015).

In the Amazon biome, the largest one in Brazil, the greatest extent of biodiversity in the world can be found (Costa et al., 2013). This biodiversity includes both flora and fauna, as well as fruit with unique sensory characteristics and increased nutrient levels (Dembitsky et al., 2011). Fruit species such as abiu (Pouteria caimito), achachairu (Garcinia humilis), araza (Eugenia stipitata), bilimbi (Averrhoa bilimbi), and yellow mangosteen (Garcinia xanthochymus) have widely appreciated flavors by Brazilian consumers and are fruits of moderate importance to the economy. They show potential for commercialization in both domestic and international markets (Rógez et al., 2004; Cavalcante et al., 2006; Lorenzi et al., 2006; Duarte, 2011; Souza et al., 2011; Garzón et al., 2012). These fruits are eaten raw; however, they can be used also in juices, ice creams, jams, and other sweets. Despite their nutritional and economic potential, these fruits lack an established commercialized market. They have still to be marketed properly because they are almost always picked from the wild. An additional consequence is that technical and scientific data on them are scarce, or nonexistent. These factors limit the consumption of these fruits to their regions of production; consequently, other national and international consumers (most of whom have more purchasing capacity) have limited access to them. Also, these fruits are not included in the Brazilian export basket items, a factor which leads to a loss in the productive potential of the Amazon region (Ribeiro \& Ferreira, 2008).

There is currently a need for interventions to stimulate small rural growers in the Amazon region to enable them to commercialize their fruits in markets that require high-quality products. Productive alternatives should also be developed to promote simultaneous species conservation, increased product value, and economic growth among rural farmers (Nobre et al., 2016).

Few scientific studies have characterized abiu, achachairu, araza, bilimbi, and yellow mangosteen fruits. The physicochemical characteristics of abiu have been determined (Canuto et al., 2010), as have those of achachairu (Pimentel, 2012), araza (Rógez et al., 2004; Canuto et al., 2010), and bilimbi (Lima et al., 2001; Araújo et al., 2009; Souza et al., 2011). Meanwhile, the bioactive compounds and total antioxidant activity have been determined in abiu (Canuto et al., 2010), achachairu (Pimentel, 2012), araza (Canuto et al., 2010; Garzón et al., 2012), and yellow mangosteen (Cavalcante et al., 2006). No studies in the literature were found to provide a combined analysis of the macronutrients and micronutrients of these fruits from the Amazon biome.

The objective of this work was to evaluate the physicochemical composition, the bioactive compounds, and the total antioxidant activity of the fruit pulps of abiu, achachairu, araza, bilimbi, and yellow mangosteen from the Brazilian Amazon biome.

\section{Materials and Methods}

Abiu, achachairu, araza, bilimbi, and yellow mangosteen fruits, from the 2012/2013 harvest (November 2012-February 2013, during the summer), were acquired directly from the growers in the city of

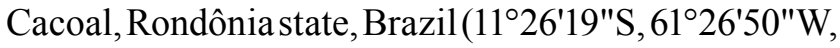
at $200 \mathrm{~m}$ altitude). According to the Köppen-Geiger's classification system for climate, the state of Rondônia has a climate that corresponds to the Aw type (tropical wet climate), with average temperatures in the coldest month above $18^{\circ} \mathrm{C}$, and a clearly defined dry season during the winter. Average annual rainfall ranges from 1,750 to $2,750 \mathrm{~mm}$. Average annual temperatures vary between $24^{\circ} \mathrm{C}$ and $26^{\circ} \mathrm{C}$, and relative humidity values stay between 80 and $85 \%$ (Climate-Data.Org, 2017).

All fruits are cultivated in the Brazilian Amazon biome (Table 1). The fruits were harvested in a sufficiently ripe state for consumption, and they all came from the same rural property. The fruits were washed, sanitized, and dried. Those which exhibited mechanical damages and visible signs of contamination on the skins were discarded. The edible portion of each fruit was mashed and homogenized to produce a pulpy mass. The pulp from the fruits (approximately $5 \mathrm{~kg}$ ) were packed in labeled plastic bags, and stored at $-18^{\circ} \mathrm{C}$ for analyses.

The fruit pulps were evaluated for their contents of moisture, protein, lipid, and ash, and for total soluble solid, titratable acidity, total and reducing sugars, and $\mathrm{pH}$, using the method described by Horwitz (2005). 
All analyses were performed in triplicate. Total caloric value was calculated as the sum of the calories (kcal) provided by carbohydrates, lipids, and protein, whose values were multiplied in grams by the respective conversion factors of $4 \mathrm{kcal} \mathrm{g}^{-1}, 9 \mathrm{kcal} \mathrm{g}^{-1}$, and $4 \mathrm{kcal} \mathrm{g}^{-1}$ (Merril \& Watt, 1973). Total carbohydrate content was defined by subtracting the protein, lipid, ash, and moisture content from $100 \%$.

Ascorbic acid content of the pulps was determined (mg ascorbic acid $100 \mathrm{~g}^{-1}$ pulp) using the method described by Horwitz (2005), and modified by Benassi \& Antunes (1988), and the analyses were performed in triplicate.

Anthocyanin and yellow flavonoid contents of the fruit pulps were determined following the method described by Francis (1982). Using the Beckman DU-640 spectrophotometer (Fullerton, CA, USA), absorbance was measured at $535 \mathrm{~nm}$ for total anthocyanin content, and at $374 \mathrm{~nm}$ for yellow flavonoid content. Yellow flavonoids and total anthocyanin contents were calculated (mg total anthocyanins or yellow flavonoids $100 \mathrm{~g}^{-1}$ of pulp) using the absorption coefficients $\left(\varepsilon_{1 \mathrm{~cm}}^{1 \%}\right)$ of 982 and 766 , respectively (Silva et al., 2014). The analyses were performed in triplicate.

Total carotenoid content of the fruit pulps was determined using the method described by RodriguezAmaya \& Kimura (2004). Absorbance was measured at $450 \mathrm{~nm}$ in the Beckman DU-640 spectrophotometer (Fullerton, CA, USA). Total carotenoid content was calculated ( $\mu \mathrm{g}$ of $\beta$-carotene $100 \mathrm{~g}^{-1}$ of pulp) using the absorption coefficients of $\beta$-carotene $\left(\varepsilon_{1 \mathrm{~cm}}^{1 \%}=2592\right)$ in petroleum ether. The analyses were performed in triplicate.

The extracts and analyses of total phenolic compounds and antioxidant activity were obtained using the methodology described by Macoris et al. (2012). Fruit pulps were blended with a 70\% acetone extraction solution. Three extracts were obtained from each type of pulp. Total phenolic compounds of fruit pulps were determined using the Folin and Ciocalteu method (Waterhouse, 2002; Macoris et al., 2012). Absorbance was measured at $720 \mathrm{~nm}$ in the Beckman DU-640 spectrophotometer (Fullerton, CA, USA). The results are expressed as $\mathrm{mg}$ gallic acid equivalent (GAE) $100 \mathrm{~g}^{-1}$ of pulp. The analyses were performed in triplicate for each type of pulp extract. Antioxidant activity of pulps was determined by capturing the ABTS - $\quad(2,2$ '-azino-bis(3-ethylbenzo-thiazoline6-sulfonic acid) diammoninum salt) free radical (Rufino et al., 2010; Macoris et al., 2012), as well as by capturing the DPPH• (2,2-diphenyl-1-picryl-hydrazyl) free radical (Rufino et al., 2010), and by measuring iron-reducing activity using the ferric reducing antioxidant power (FRAP) assay (TPTZ reagent: 2,4,6-Tris (2-pyridyl)-s-triazine) (Rufino et al., 2010). Absorbance was measured in the Beckman DU-640 spectrophotometer (Fullerton, CA, USA) at $734 \mathrm{~nm}$ for ABTS method, at $515 \mathrm{~nm}$ for DPPH method, and at $595 \mathrm{~nm}$ for FRAP method. The analyses were performed in triplicate for each fruit-type pulp extract, and the results were expressed as $\mu \mathrm{mol}$ of trolox 100 $\mathrm{g}^{-1}$ of pulp.

The results of each parameter of fruit pulps were subjected to the analysis of variance, followed by the Tukey's test, in order to compare the means. The differences were considered significant at 5\% probability. A linear correlation analysis was also performed, which considered the contents of ascorbic acid, total carotenoids, anthocyanin, yellow flavonoids, total phenolic compounds, and the antioxidant activity. The physicochemical means were fixed in columns (variables), and the different pulps of fruits were fixed in rows (cases). The data were standardized before analyses. The principal component analysis (PCA) was performed with a correlation matrix, without the factor rotation. Percentage variations greater than

Table 1. Common name, scientific name, family, and analyzed edible and nonedible portions of fruits from the Brazilian Amazon biome.

\begin{tabular}{|c|c|c|c|c|}
\hline Common name & Scientific name & Family & Edible portion & Nonedible portion \\
\hline Abiu & Pouteria caimito (Ruiz \& Pav.) Radlk. & Sapotaceae & Pulp & Peel and seed \\
\hline Achachairu & Garcinia humilis (Vhal) C. D. Adam & Clusiaceae & Pulp & Peel and seed \\
\hline Araza & Eugenia stipitata McVaugh & Myrtaceae & Pulp & Peel and seed \\
\hline Bilimbi & Averrhoa bilimbi L. & Oxalidaceae & Pulp and Peel & Seed \\
\hline Yellow mangosteen or false mangosteen & Garcinia xanthochymus Hook. f. & Clusiaceae & Pulp & Peel and seed \\
\hline
\end{tabular}


$70 \%$, explained by the two first principal components, indicate a strong correlation among variables, and they also indicate that PCA is an appropriate multivariate analysis to be applied to the data. Cluster analysis was performed with Euclidean distances as the distance measurements, and Ward's hierarchy was applied as the amalgamation rule to the individual data from each species pulp. The midpoint of the largest increment was used to separate the groups. Multidimensional scaling analysis was then applied to the resulting correlation matrix, which considered the chemical makeup, bioactive components, and antioxidant activity of each fruit pulp. Multidimensional scaling analysis is a multivariate technique based on proximities between objects (pulps), which are used to produce a spatial representation of these items.

The Statistica 7.0 software (StatSoft, Tulsa, OK, USA) was employed for the analyses.

\section{Results and Discussion}

The physicochemical composition of the fruit pulps from the Brazilian Amazon biome showed significant differences among the evaluated parameters (Table 2).

Abiu showed the highest values for total soluble solids, reducing sugars, total sugars, $\mathrm{pH}$, protein, lipid, ash, and total calories, and the lowest values for titratable acidity, and moisture. Achachairu had the highest value for titratable acidity, and the lowest value for lipid content. Araza showed the lowest values for total soluble solids, reducing sugars, total sugars, $\mathrm{pH}$, and ash. Bilimbi showed the highest values for moisture, and the lowest values for total calories. Yellow mangosteen showed the lowest-protein content.
The analyzed fruit pulps do not have identity and quality standards in the current Brazilian laws for comparison.

Pimentel (2012) analyzed the achachairu pulp from the Brazilian state of Pernambuco. The pulp was found to have $78.95 \%$ moisture, $0.24 \%$ ash content, $0.48 \%$

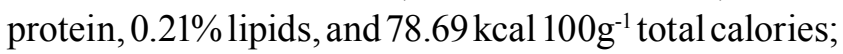
these amounts differed from those of the present study. When analyzed by Canuto et al. (2010), the abiu pulp from the Amazon biome was found to have $3.8^{\circ}$ Brix total soluble solids, a value which was lower than that found in the present study. Meanwhile, their titratable acidity content of $5.9 \mathrm{mg}$ of citric acid $100 \mathrm{~g}^{-1}$ was higher than that of the present study. The lipid content $\left(0.1 \mathrm{~g}^{100 \mathrm{~g}^{-1}}\right)$ and $\mathrm{pH}(5.0)$ were similar to those found in the present study. In a study on araza (Garzón et al., 2012), data on soluble solids (4.6 $\left.{ }^{\circ} \mathrm{Brix}\right)$ and on $\mathrm{pH}$ (2.6) were similar to those of the present study. A study on bilimbi by Araújo et al. (2009) found total soluble solids ( $\left.3.23^{\circ} \mathrm{Brix}\right)$ and $\mathrm{pH}(2.49)$, similar to those of the present study. Souza et al. (2011) studied the bilimbi, and reported $4.95 \%$ soluble solids, and $5.10 \%$ oxalic acid in total titratable acidity. Yellow mangosteen pulp (Cavalcante et al., 2006) from Jaboticabal, SP, Brazil, was found to have $11.73{ }^{\circ} \mathrm{Brix}$ total soluble solids, and $4.19 \%$ titratable acidity contents, which are higher than those found in the current study. The physicochemical characteristics of the fruits may vary as a result of many factors, including weather conditions, location, use of pesticides, state of ripeness, processing, and storage (Souza et al., 2012).

Fruits are part of one of the food groups that are richest in bioactive compounds. They provide a series of health benefits, particularly because they

Table 2. Physicochemical composition of fruit pulps from the Brazilian Amazon biome ${ }^{(1)}$.

\begin{tabular}{|c|c|c|c|c|c|}
\hline Parameter & Abiu & Achachairu & Araza & Bilimbi & Yellow mangosteen \\
\hline Total soluble solids ( ${ }^{\circ}$ Brix $)$ & $16.20 \pm 0.01 \mathrm{a}$ & $10.50 \pm 0.01 \mathrm{~b}$ & $3.00 \pm 0.00 \mathrm{e}$ & $4.00 \pm 0.1 d$ & $9.00 \pm 0.01 \mathrm{c}$ \\
\hline Reducing sugars (g glucose $100 \mathrm{~mL}^{-1}$ pulp) & $6.62 \pm 0.05 \mathrm{a}$ & $5.60 \pm 0.07 b$ & $0.48 \pm 0.01 \mathrm{~d}$ & $3.19 \pm 0.05 \mathrm{c}$ & $6.47 \pm 0.20 \mathrm{a}$ \\
\hline Total sugars (g glucose $100 \mathrm{~mL}^{-1}$ pulp) & $14.70 \pm 0.09 \mathrm{a}$ & $7.44 \pm 0.10 \mathrm{c}$ & $1.18 \pm 0.01 \mathrm{e}$ & $3.27 \pm 0.05 \mathrm{~d}$ & $8.15 \pm 0.30 b$ \\
\hline Titratable acidity (g citric acid $100 \mathrm{~g}^{-1}$ pulp) & $0.04 \pm 0.01 d$ & $2.87 \pm 0.01 \mathrm{a}$ & $2.83 \pm 0.03 \mathrm{a}$ & $0.94 \pm 0.03 \mathrm{c}$ & $1.39 \pm 0.04 b$ \\
\hline $\mathrm{pH}$ & $6.89 \pm 0.11 \mathrm{a}$ & $2.97 \pm 0.02 \mathrm{c}$ & $2.67 \pm 0.06 \mathrm{~d}$ & $2.83 \pm 0.02 \mathrm{c}$ & $3.30 \pm 0.01 b$ \\
\hline Moisture (\%) & $81.87 \pm 0.19 \mathrm{~d}$ & $87.30 \pm 0.94 \mathrm{c}$ & $94.42 \pm 0.10 \mathrm{a}$ & $95.40 \pm 0.04 \mathrm{a}$ & $89.04 \pm 0.13 b$ \\
\hline Protein $(\%)$ & $4.97 \pm 0.08 \mathrm{a}$ & $3.23 \pm 0.07 b$ & $3.04 \pm 0.05 \mathrm{c}$ & $3.11 \pm 0.03 \mathrm{bc}$ & $1.70 \pm 0.01 d$ \\
\hline Lipid (\%) & $0.15 \pm 0.01 \mathrm{a}$ & $0.02 \pm 0.01 d$ & $0.06 \pm 0.01 \mathrm{c}$ & $0.02 \pm 0.01 \mathrm{~d}$ & $0.11 \pm 0.01 \mathrm{~b}$ \\
\hline Ash $(\%)$ & $0.49 \pm 0.02 \mathrm{a}$ & $0.32 \pm 0.01 \mathrm{c}$ & $0.19 \pm 0.01 \mathrm{e}$ & $0.25 \pm 0.01 \mathrm{~d}$ & $0.38 \pm 0.01 b$ \\
\hline Total caloric value ( $\mathrm{kcal} 100 \mathrm{~g}^{-1}$ pulp) & $71.36 \pm 0.97 \mathrm{a}$ & $47.47 \pm 0.90 b$ & $21.82 \pm 0.46 \mathrm{~d}$ & $17.45 \pm 0.22 \mathrm{e}$ & $42.99 \pm 0.51 \mathrm{c}$ \\
\hline
\end{tabular}

${ }^{(1)}$ Means \pm standard deviation ( $\left.\mathrm{n}=3\right)$, followed by same letter on the line, do not differ, according to the Tukey's test, at $5 \%$ probability. 
act as antioxidants (Liu, 2013). Ascorbic acid content of the analyzed fruit pulps had the lowest values in abiu, and the highest ones in yellow mangosteen (Table 3). The daily recommended vitamin $\mathrm{C}$ intake (or daily recommended allowance) for adults is $90 \mathrm{mg}$ for men, and $75 \mathrm{mg}$ for women, and the maximum tolerable intake limit (or tolerable upper intake level) is $2 \mathrm{~g}$ per day (United States, 2000). According to the current Brazilian laws (Anvisa, 2012), for a food to be considered a "source" of vitamins, or a product with a "high content" of vitamins, $100 \mathrm{~g}$ or $100 \mathrm{~mL}$ of the food should contain 15 or $30 \%$ of the daily recommended allowance, respectively. From the analyzed fruits, yellow mangosteen can be considered a "source" of vitamin $C$, and could be marketed to female consumers, since $100 \mathrm{~g}$ of pulp contains $15.36 \%$ of their daily recommended allowance. Pimentel (2012) observed $0.90 \mathrm{mg} 100 \mathrm{~g}^{-1}$ ascorbic acid content, in a study on achachairu, a value much lower than the obtained one in the present study. Cavalcante et al. (2006) found $40.32 \mathrm{mg} 100 \mathrm{~g}^{-1}$ ascorbic acid content, a much higher content than the ones reported here for yellow mangosteen, although their study used very different methods. Araújo et al. (2009) reported higher-ascorbic acid contents for bilimbi, at different stages of ripeness (50.82 mg $100 \mathrm{~g}^{-1}$ in unripe fruit, $41.69 \mathrm{mg} 100 \mathrm{~g}^{-1}$ in

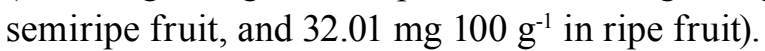

Yellow flavonoid content had the lowest value in the abiu pulp, and the highest one in the yellow mangosteen pulp (Table 3). The content of yellow flavonoids in the yellow mangosteen pulp, found in the present study, was higher than the value reported by Rufino et al. (2010). The fruit pulps from the Amazon biome that were analyzed herein were found to contain low-anthocyanin contents (lower than the limit of quantification of $1 \mathrm{mg}$ of anthocyanins $100 \mathrm{~g}^{-1}$ of pulp).

Carotenoids are natural pigments with many biological functions (Liu, 2013). $\beta$-carotene is commonly found in foods, and it is known for its provitamin A activity (Rodriguez-Amaya \& Kimura, 2004). Abiu showed the lowest value of total carotenoid content, and araza showed the highest value for this parameter. In their analysis of araza, Garzón et al. (2012) reported much higher-total carotenoid values than those found in the present study $(806 \mu \mathrm{g}$ $\beta$-carotene $100 \mathrm{~g}^{-1}$ pulp).

When it came to total phenolic compounds, the bilimbi pulp showed the lowest values, and the achachairu pulp showed the highest values. The total phenolic compound content (19.3 mg GAE $100 \mathrm{~g}^{-1}$ ) of araza from the Colombian Amazon (Garzón et al., 2012) was lower than the value found in the present study. The achachairu pulp analyzed by Pimentel (2012) was found to have lower-total phenolic compound content (104.58 and $264.43 \mathrm{mg}$ GAE $100 \mathrm{~g}^{-1}$ in hydromethanolic extracts and hydroacetone extracts, respectively) than the pulp analyzed in the present study. Vasco et al. (2008) classified the fruits as for polyphenol content and placed them into three categories: low ( $<100 \mathrm{mg} 100 \mathrm{~g}^{-1}$ of GAE), moderate

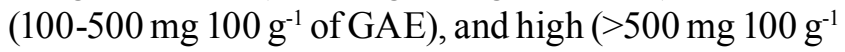
of GAE) content. This classification has been used in other studies (Rufino et al., 2010; Souza et al., 2012). Thus, bilimbi pulp can be classified as having lowpolyphenol content, while abiu, achachairu, araza, and yellow mangosteen pulps can be classified as having moderate quantities of polyphenol content. The FolinCiocalteu reagent is frequently used in colorimetric in vitro assays because it is simple, and exhibits strong

Table 3. Bioactive compounds and antioxidant activity in the pulp of fruits from the Brazilian Amazon biome ${ }^{(1)}$.

\begin{tabular}{|c|c|c|c|c|c|}
\hline Parameter & Abiu & Achachairu & Araza & Bilimbi & Yellow mangosteen \\
\hline Ascorbic acid (mg $100 \mathrm{~g}^{-1}$ pulp) & $3.06 \pm 0.03 \mathrm{~d}$ & $5.60 \pm 0.07 \mathrm{c}$ & $5.60 \pm 0.01 \mathrm{c}$ & $9.92 \pm 0.29 b$ & $11.52 \pm 0.09 \mathrm{a}$ \\
\hline Yellow flavonoids (mg $100 \mathrm{~g}^{-1}$ pulp) & $1.56 \pm 0.03 \mathrm{~d}$ & $5.55 \pm 0.10 \mathrm{~b}$ & $2.55 \pm 0.04 \mathrm{c}$ & $2.14 \pm 0.04 \mathrm{c}$ & $50.50 \pm 0.53 \mathrm{a}$ \\
\hline Total carotenoids ( $\mu \mathrm{g} \beta$-carotene $100 \mathrm{~g}^{-1}$ pulp) & $25.55 \pm 0.07 \mathrm{e}$ & $61.39 \pm 0.04 \mathrm{~d}$ & $380.77 \pm 7.13 \mathrm{a}$ & $125.42 \pm 3.73 \mathrm{c}$ & $165.48 \pm 0.87 b$ \\
\hline Total phenolic compounds (mg GAE $100 \mathrm{~g}^{-1}$ pulp) & $172.75 \pm 0.77 b$ & $341.73 \pm 1.48 \mathrm{a}$ & $122.78 \pm 2.52 \mathrm{c}$ & $40.16 \pm 0.18 \mathrm{e}$ & $100.55 \pm 2.78 \mathrm{~d}$ \\
\hline $\mathrm{ABTS}^{+}\left(\mu \mathrm{mol}\right.$ trolox $100 \mathrm{~g}^{-1}$ pulp $)$ & $1459.26 \pm 0.40 \mathrm{bc}$ & $3449.30 \pm 10.67 \mathrm{a}$ & $1209.72 \pm 0.01 \mathrm{bc}$ & $168.49 \pm 0.20 \mathrm{c}$ & $2670.31 \pm 3.71 \mathrm{ab}$ \\
\hline DPPH $\left(\mu\right.$ mol trolox $100 \mathrm{~g}^{-1}$ pulp $)$ & $734.98 \pm 0.26 b$ & $861.83 \pm 0.35 \mathrm{a}$ & $472.15 \pm 0.40 \mathrm{c}$ & $140.21 \pm 0.01 \mathrm{~d}$ & $641.73 \pm 0.31 b$ \\
\hline FRAP $\left(\mu\right.$ mol trolox $100 \mathrm{~g}^{-1}$ pulp $)$ & $1211.03 \pm 1.12 b$ & $2995.88 \pm 3.23 \mathrm{a}$ & $1652.91 \pm 0.72 b$ & $322.70 \pm 0.29 \mathrm{c}$ & $489.39 \pm 0.48 \mathrm{c}$ \\
\hline
\end{tabular}

${ }^{(1)}$ Means \pm standard deviation ( $\mathrm{n}=3$ ), followed by different letters on the same line, do not differ according to Tukey's test, at $5 \%$ probability. GAE, gallic acid equivalent. ABTS ${ }^{+}, 2$,2'-azino-bis(3-ethylbenzo-thiazoline-6-sulfonic acid) diammoninum salt; DPPH, 2,2-diphenyl-1-picryl-hydrazyl; FRAP, ferric reducing antioxidant power. 
reproducibility. This method is employed to quantify all classes of polyhydroxy phenolic compounds. However, other nonphenolic compounds, such as ascorbic acid, certain sugars, and amino acids may also react with the Folin-Ciocalteu reagent (Rocha et al., 2011; Wootton-Beard \& Ryan, 2011; Macoris et al., 2012). Due to the low concentration of ascorbic acid and sugars in the analyzed fruits in the present study, an extraction step was not necessary to remove these interferents.

The ABTS, DPPH, FRAP, and orygen radical absorbance capacity (ORAC) methods used to determine the antioxidant activity are most commonly used in fruits. Pérez-Jiménez et al. (2008) recommend using more than one method (and preferably all of them), in order to acquire more complete information on the antioxidant capacity of foods. This variety of testing allows researchers to consider the advantages or disadvantages of each method, as well as each method's acceptability. In all the applied assays herein, the achachairu pulp was found to have the highest antioxidant activity, and the bilimbi pulp was found to have the lowest one (Table 3). Garzón et al. (2012) studied araza, and reported a total antioxidant activity of $1.2 \mu \mathrm{mol} \mathrm{g}^{-1}$ of trolox when using the ABTS, $0.8 \mu \mathrm{mol} \mathrm{g}^{-1}$ of trolox when using the DPPH, and $3.5 \mu \mathrm{mol} \mathrm{g}^{-1}$ of trolox when using the FRAP method; all these values are lower than those found in the present study. The ABTS, DPPH, and FRAP methods showed a correlation only between antioxidant activity and total phenolic compounds $(\mathrm{r}=0.784, \mathrm{p} \leq 0.05 ; \mathrm{r}=0.829, \mathrm{p} \leq 0.05$; and $\mathrm{r}=0.936, \mathrm{p} \leq 0.05$, respectively). This correlation suggests that phenolic compound contents are the most important factor for determining the antioxidant activity in the analyzed fruit pulps. A positive linear correlation between antioxidant activity and total phenolic compounds has also been reported in other studies on fruits (Thaipong et al., 2006; Macoris et al., 2012).

A principal component analysis was used to better visualize the physicochemical parameter, bioactive compounds, and antioxidant activity of the pulps of fruits (2012-2013 harvest) from the Amazon biome (Figure $1 \mathrm{~A}$ ). The two first main components accounted for $76.54 \%$ of the variance. The first main component was positively associated with the moisture content and total carotenoid parameters, and it was negatively associated with ash content, total sugars, reducing sugars, total soluble solids, carbohydrates,

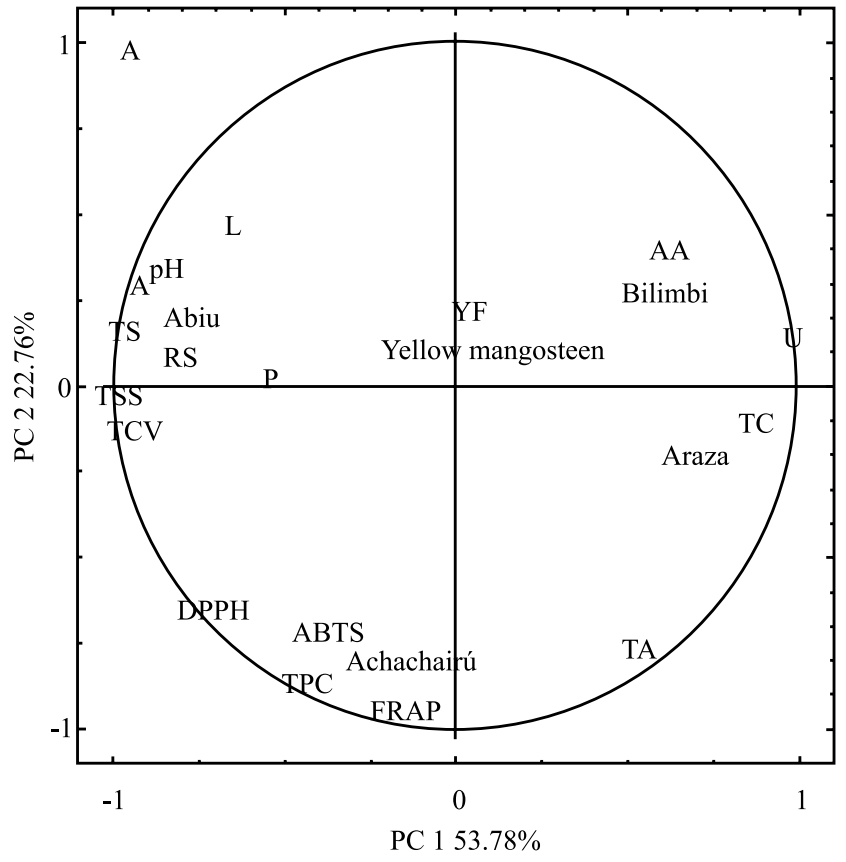

B

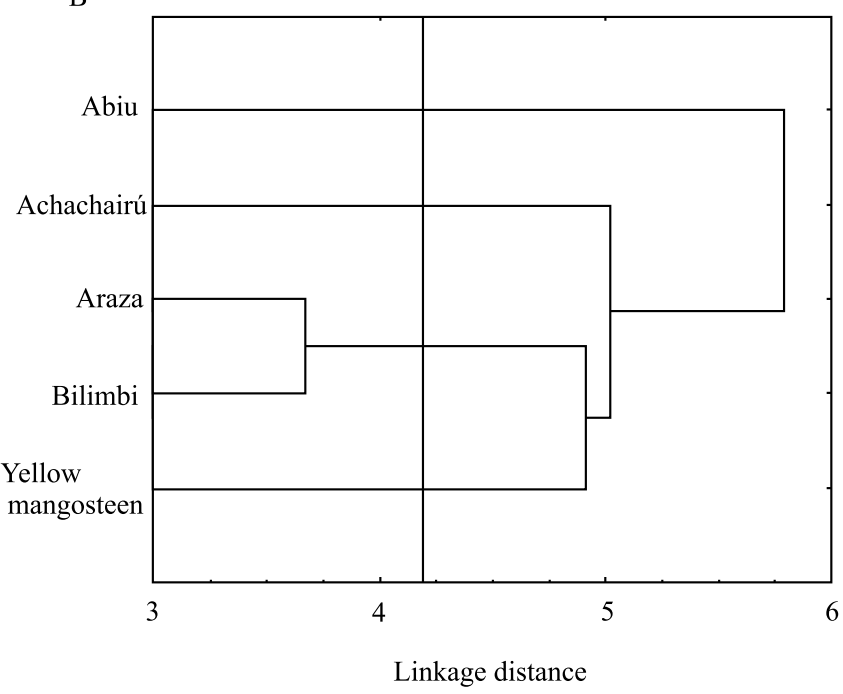

Figure 1. Principal component analysis (A) and dendrogram (B) of the physicochemical parameters, bioactive compounds, and antioxidant activity of pulps of the fruits abiu, achachairu, araza, bilimbi, and yellow mangosteen, from the Brazilian Amazon biome. TSS, total soluble solids; RS, reducing sugars; TS, total sugars; TA, titratable acidity; AA, ascorbic acid; YF, yellow flavonoids; TC, total carotenoids; TPC, total phenolic compounds; $\mathrm{M}$, moisture; $\mathrm{P}$, protein; L, lipid; A, ash; C, carbohydrates; TCV, total caloric value. 
total calories, and $\mathrm{pH}$. The second main component was negatively associated with titratable acidity, total phenolic compounds, and antioxidant activity values acquired using the ABTS, DPPH, and FRAP assays. The fruit pulps were placed in different quadrants because their characteristics are all very different (Figure $1 \mathrm{~B}$ ). The achachairu pulp was characterized to have the highest titratable acidity content, the largest phenolic compound content, and the highest antioxidant activity in the ABTS, DPPH, and FRAP assays. The yellow mangosteen pulp was characterized to have the highest yellow flavonoid content, while the abiu pulp was characterized to have the highest contents for ash, protein, lipid, total sugars, reducing sugars, and total soluble solids, besides total calories, and $\mathrm{pH}$. The araza pulp was characterized to contain the highest carotenoid content and moisture content. Meanwhile, the bilimbi pulp was characterized to have the highest ascorbic acid content.

These results can help the small-scale rural farmers in the Brazilian Amazon region to get their fruits marketed as high-quality products, and can also provide information that can contribute to the development of new products with higher concentration of nutrients and, therefore, of greater value. Abiu, achachairu, araza, bilimbi, and the yellow mangosteen fruits from other harvests in the Brazilian Amazon biome should be evaluated in further researches, in order to confirm the results obtained in the present study on their physicochemical parameters and bioactive compounds.

\section{Conclusions}

1. The fruits abiu (Pouteria caimito), achachairu (Garcinia humilis), araza (Eugenia stipitata), bilimbi (Averrhoa bilimbi), and yellow mangosteen (Garcinia xanthochymus) show moisture contents above $80 \%$ and low-lipid contents; and araza and bilimbi are considered low-calorie fruits.

2. As to bioactive components, the achachairu pulp has the highest-total phenolic compound content, while the araza pulp has the highest-carotenoid content, and the yellow mangosteen pulp has the highest-yellow flavonoid content.

3. The antioxidant activity in these fruits is highly correlated with total-phenolic compound content.

\section{Acknowledgments}

To Coordenação de Aperfeiçoamento de Pessoal de Nível Superior (Capes), for the scholarship granted; and to Universidade Estadual Paulista (Unesp/Prope), for financial support.

\section{References}

ANUÁRIO BRASILEIRO DA FRUTICULTURA 2014. Santa Cruz do Sul: Gazeta Santa Cruz, 2015. 104p.

ANVISA. Agência Nacional de Vigilância Sanitária. Resolução $\mathrm{RDCn}^{\circ}$ 54, de 12 de novembro de 2012. Dispõe sobre o Regulamento Técnico sobre Informação Nutricional Complementar. Diário Oficial da União, 13 nov. 2012. Seção 1, p.122-126.

ARAÚJO, E.R.; ALVES, L.I.F.; RÊGO, E.R. do; RÊGO, M.M. do; CASTRO, J.P. de; SAPUCAY, M.J.L. da C. Caracterização físicoquímica de frutos de biri-biri (Averrhoa bilimbi L.). Biotemas, v.22, p.225-230, 2009. DOI: 10.5007/2175-7925.2009v22n4p225.

BENASSI, M. de T.; ANTUNES, A.J. Comparison of metaphosphoric and oxalic acids as extractants solutions for the determination of vitamin $\mathrm{C}$ in selected vegetables. Arquivos de Biologia e Tecnologia, v.31, p.507-513, 1988.

CANUTO, G.A.B.; XAVIER, A.A.O.; NEVES, L.C.; BENASSI, M. de T. Caracterização físico-química de polpas de frutos da Amazônia e sua correlação com a atividade anti-radical livre. Revista Brasileira de Fruticultura, v.32, p.1196-1205, 2010. DOI: $10.1590 / \mathrm{S} 0100-29452010005000122$.

CARTER, P.; GRAY, L.J.; TROUGHTON, J.; KHUNTI, K.; DAVIES, M.J. Fruit and vegetables intake and incidence on type 2 diabetes mellitus: systematic review and meta-analysis. British Medical Journal, v.341, p.c4229, 2010. DOI: 10.1136/bmj.c4229.

CAVALCANTE, I.H.L.; JESUS, N. de; MARTINS, A.B.G. Physical and chemical characterization of yellow mangosteen fruits. Revista Brasileira de Fruticultura, v.28, p.325-327, 2006. DOI: 10.1590/S0100-29452006000200039.

CLIMATE-DATA.ORG. Clima: Cacoal. Available at: $<$ https:// pt.climate-data.org/location/31797/>. Accessed on: Apr. 72017.

COSTA, A.G.V.; GARCIA-DIAZ, D.F.; JIMENEZ, P.; SILVA, P.I. Bioactive compounds and health benefits of exotic tropical redblack berries. Journal of Functional Foods, v.5, p.539-549, 2013. DOI: 10.1016/j.jff.2013.01.029.

DEMBITSKY, V.M.; POOVARODOM, S.; LEONTOWICZ, H.; LEONTOWICZ, M.; VEARASILP, S.; TRAKHTENBERG, S.; GORINSTEIN, S. The multiple nutrition properties of some exotic fruits: biological activity and active metabolites. Food Research International, v.44, p.1671-1701, 2011. DOI: 10.1016/j. foodres.2011.03.003.

DUARTE, O. Achachairú (Garcinia humilis (Vhal) C. D. Adam). Postharvest Biology and Technology of Tropical and Subtropical Fruits: Açai to Citrus, v.54e, p.48-53, 2011.

FAO. Food and Agriculture Organization of the United Nations. Top fruit producers and their productivity. In: FAO. Food and 
Agriculture Organization of the United Nations. FAO Statistical Yearbook 2013. Rome: FAO, 2013.

FRANCIS, F.J. Analysis of anthocyanins in foods. In: MARKAKIS, P. (Ed.). Anthocyanins as food colors. New York: Academic Press, 1982. p.181-207. DOI: 10.1016/B978-0-12472550-8.50011-1.

GARZÓN, G.A.; NARVÁEZ-CUENCA, C.-E.; KOPEC, R.E.; BARRY, A.M.; RIEDL, K.M.; SCHWARTZ, S.J. Determination of carotenoids, total phenolic content, and antioxidant activity of Arazá (Eugenia stipitata McVaugh), an Amazonian fruit. Journal of Agricultural and Food Chemistry, v.60, p.4709-4717, 2012. DOI: $10.1021 /$ jf205347f.

HORWITZ, W. (Ed.). Official Methods of Analysis of the AOAC International. $18^{\text {th }}$ ed. Gaithersburg: Association of Official Analytical Chemists, 2005. 771p.

LIMA, V.L.A.G. de; MÉLO, E. de A.; LIMA, L. dos S. Physicochemical characteristics of bilimbi (Averrhoa bilimbi L). Revista Brasileira de Fruticultura, v.23, p.421-423, 2001. DOI: 10.1590/S0100-29452001000200045.

LIU, R.H. Health-promoting components of fruits and vegetables in the diet. Advances in Nutrition an International Review Journal, v.4, p.384S-392S, 2013. DOI: 10.3945/an.112.003517.

LORENZI, H.; BACHER, L.; LACERDA, M.; SARTORI, S. Frutas brasileiras e exóticas cultivadas (de consumo in natura). São Paulo: Instituto Plantarum de Estudos da Flora, 2006.

MACORIS, M.S.; DE MARCHI, R.; JANZANTTI, N.S.; MONTEIRO, M. The influence of ripening stage and cultivation system on the total antioxidant activity and total phenolic compounds of yellow passion fruit pulp. Journal of the Science of Food Agriculture, v.92, p.1886-1891, 2012. DOI: 10.1002/ jsfa.5556.

MERRIL, A.L.; WATT, B.K. Energy value of foods: ... basis and derivation. Washington: Usda, 1973. (Usda. Agriculture Handbook, 74).

NOBRE, C.A.; SAMPAIO, G.; BORMA, L.S.; CASTILLARUBIO, J.C.; SILVA, J.S.; CARDOSO, M. Land-use and climate change risks in the Amazon and the need of a novel sustainable development paradigm. Proceedings of the National Academy of Sciences of the United States of America, v.113, p.1075910768, 2016. DOI: 10.1073/pnas.1605516113.

PÉREZ-JIMÉNEZ, J.; ARRANZ, S.; TABERNERO, M.; DÍAZRUBIO, M.E.; SERRANO, J.; GOÑI, I.; SAURA-CALIXTO, F. Updated methodology to determine antioxidant capacity in plant foods, oils and beverages: extraction, measurement and expression of results. Food Research International, v.41, p.274285, 2008. DOI: 10.1016/j.foodres.2007.12.004.

PIMENTEL, M.R. da F. Caracterização qualitativa de frutos de achachairu (Garcinia humilis (Vahl) C. D. Adam) cultivados em Moreno-PE. 2012. 76p. Dissertação (Mestrado) - Universidade Federal Rural de Pernambuco, Recife. Available at: <http://www.tede2.ufrpe.br:8080/tede2/handle/tede2/5091>. Accessed on: Apr. 72017.

RIBEIRO, G.D.; FERREIRA, M. das G.R. Comportamento inicial de duas fruteiras amazônicas e duas exóticas tropicais, em Porto Velho, Rondônia: abiu gigante (Pouteria caimito (Ruiz \& Pav.) Radlk), araçá-boi (Eugenia stipitata Mc Vaugh.), abricó (Mammea americana Jacq.) e rambutan (Nephelium lappaceum L.). Porto Velho: Embrapa Rondônia, 2008. (Embrapa Rondônia. Comunicado técnico, 355).

ROCHA, W.S.; LOPES, R.M.; SILVA, D.B. da; VIEIRA, R.F.; SILVA, J.P. da; AGOSTINI-COSTA, T. da S. Compostos fenólicos totais e taninos condensados em frutas nativas do Cerrado. Revista Brasileira de Fruticultura, v.33, p.1215-1221, 2011. DOI: 10.1590/S0100-29452011000400021.

RODRIGUEZ-AMAYA, D.B.; KIMURA, M. HarvestPlus Handbook of Carotenoid Analysis. Washington: IFPRI; Cali: CIAT, 2004.

RÓGEZ, H.; BUXANT, R.; MIGNOLET, E.; SOUZA, J.N.S.; SILVA, E.M.; LARONDELLE, Y. Chemical composition of the pulp of three typical Amazonian fruits: araça-boi (Eugenia stipitata), bacuri (Platonia insignis) and cupuaçu (Theobroma grandiflorum). European Food Research and Technology, v.218, p.380-384, 2004. DOI: 10.1007/s00217-003-0853-6.

RUFINO, M. do S.M.; ALVES, R.E.; BRITO, E.S. de; PÉREZGIMÉNEZ, J.; SAURA-CALIXTO, F.; MANCINI-FILHO, J. Bioactive compounds and antioxidant capacities of 18 nontraditional tropical fruits from Brazil. Food Chemistry, v.121, p.996-1022, 2010. DOI: 10.1016/j.foodchem.2010.01.037.

SILVA, L.M.R. da; FIGUEIREDO, E.A.T. de; RICARDO, N.M.P.S.; VIEIRA, I.G.P.; FIGUEIREDO, R.W. de; BRASIL, I.M.; GOMES, C.L. Quantification of bioactive compounds in pulps and by-products of tropical fruits from Brazil. Food Chemistry, v.143, p.398-404, 2014. DOI: 10.1016/j.foodchem.2013.08.001.

SOUZA, P.A. de; SENHOR, R.F.; COSTA, F.B. da; FREITAS, R.V. da S.; SILVA, M.S. Caracterização físico-química de frutos de bilimbí (Averrhoa bilimbi L.) produzidos no estado do RN. Revista Verde, v.6, p.270-273, 2011.

SOUZA, V.R. de; PEREIRA, P.A.P.; QUEIROZ, F.; BORGES, S.V.; CARNEIRO, J. de D.S. Determination of bioactive compounds, antioxidant activity and chemical composition of Cerrado Brazilian fruits. Food Chemistry, v.134, p.381-386, 2012. DOI: 10.1016/j.foodchem.2012.02.191.

THAIPONG, K.; BOONPRAKOB, U.; CROSBY, K.; CISNEROSZEVALLOS, L.; BYRNE, D.H. Comparison of ABTS, DPPH, FRAP and ORAC assays for estimating antioxidant activity from guava fruit extracts. Journal of Food Composition and Analysis, v.19, p.669-675, 2006. DOI: 10.1016/j.jfca.2006.01.003.

UNITED STATES. Institute of Medicine. Dietary reference intakes for vitamin $C$, vitamin $E$, selenium and carotenoids. Washington: National Academic Press, 2000.

VASCO, C.; RUALES, J.; KAMAL-ELDIN, A. Total phenolic compounds and antioxidant capacities of major fruits from Ecuador. Food Chemistry, v.111, p.816-823, 2008. DOI: 10.1016/j. foodchem.2008.04.054.

WANG, S.; MELNYK, J.P.; TSAO, R.; MARCONE, M.F. How natural dietary antioxidants in fruits, vegetables and legumes promote vascular health. Food Research International, v. 44, p.14-22, 2011. DOI: 10.1016/j.foodres.2010.09.028. 
WATERHOUSE, A.L. Folin-Ciocalteau Micro Method for Total Phenol in Wine. 2002. Available at: <http://waterhouse. ucdavis.edu/faqs/folin-ciocalteau-micro-method-for-totalphenol-in-wine>. Accessed on: Oct. 302014.
WOOTTON-BEARD, P.C.; RYAN, L. Improving public health?: The role of antioxidant-rich fruit and vegetable beverages. Food Research International, v.44, p.3135-3148, 2011. DOI: 10.1016/j. foodres.2011.09.015.

$\overline{\text { Received on July 5, } 2016 \text { and accepted on March 6, } 2017}$ 